ВІСНИК

ОДЕСЬКОГО НАЦІОНАЛЬНОГО

МОРСЬКОГО УНІВЕРСИТЕТУ

№ 2 (59), 2019
HERALD

OF THE ODESSA NATIONAL

MARITIME UNIVERSITY № 2 (59), 2019

УДК 629.541.4

DOI 10.33082/2226-1915 -2-2019-77-90

\title{
ЗАСТОСУВАННЯ ЙМОВІРНІСНИХ МЕТОДІВ ОЦІНКИ РИЗИКІВ МОДЕРНІЗАЦІЇ ПАСАЖИРСЬКИХ СУДЕН ВНУТРІШНЬОГО ТА ЗМІШАНОГО ПЛАВАННЯ
}

\author{
Л.М. Кукалець \\ старший викладач \\ кафедри Суднових енергетичних установок, допоміжних механізмів та їх експлуатації
}

Державний університет інфраструктури та технологій

Анотація. Обтрунтовано доцільність застосування методики формалізованої оцінки ризиків IMO, ідентифіковані фактори, що зумовлюють необхідність проведення модернізачії пасажсирських суден, проведено ймовірнісну оцінку впливу небезпек на модернізацію судна та визначено формалізований рівень комериійного ризику. За результатами дос-лідження, моральне старіння судна визначено, як максимальний фактор, щуо призводить до застосування одного (або декількох) напрямів модернізаиії.

Ключові слова: пасажирське судно, модернізачія, моральне старіння, фактори ризику, ідентифікаиія небезпек.

УДК 629.541.4

DOI 10.33082/2226-1915 -2-2019-77-90

\section{ПРИМЕНЕНИЕ ВЕРОЯТНОСТНЫХ МЕТОДОВ ОЦЕНКИ РИСКОВ МОДЕРНИЗАЦИИ ПАССАЖИРСКИХ СУДОВ ВНУТРЕННЕГО И СМЕШАННОГО ПЛАВАНИЯ}

\author{
Л.Н. Кукалец \\ старший преподаватель кафедры Судовых энергетических установок, \\ вспомогательных механизмов и их эксплуатации \\ Государственный университет инфраструктурь и технологий
}

Аннотация. Обоснована целесообразность применения методики формализованной оиенки рисков ИМО, идентифицированы факторы, обусловливающие необходимость проведения модернизации судов, проведена вероятностная оиенка влияния опасностей на модернизацию судна и определен формализованный уровень коммерческого риска.

(C) Кукалець Л.М., 2019 
По результатам исследования, моральное старение судна определено, как максимальный фактор, приводящуий к применению одного (или нескольких) направлений модернизации.

Ключевые слова: пассажирское судно, модернизация, моральное старение, факторы риска, идентификация опасностей.

UDC 629.541.4

DOI 10.33082/2226-1915 -2-2019-77-90

\title{
THE USE OF PROBABILISTIC METHODS FOR ASSESSING THE RISKS OF THE MODERNIZATION OF INLAND AND MIXED VESSELS
}

\author{
L. Kukalets \\ Senior Lecturer at the Department of Ship`s Power Plants, \\ Auxiliary Machinery and their Operation
}

State University of Infrastructure and Technology

Abstract. The article rationalizes using the methodology of formalized IMO risk assessment, identifies the reasons that lead to ship modernization. The paper also provides a probability assessment of the impact of hazards on ship modernization and determines the formalized level of commercial risk. According to the research results, the obsolescence of the vessel is defined as the maximum factor, which leads to the application of one (or several) directions of modernization.

Keywords: passenger ship, modernization, obsolescence, risk factors, hazards identification.

Постановка проблеми. Модернізація пасажирських круїзних суден (ПКС ВЗП) охоплює декілька основних напрямів: реновація, реконструкція, рекласифікація, переобладнання, дообладнання та конверсія. Кожен 3 них має свій притаманний йому перелік робіт - як основних, так і супутніх [1]. Визначення напрямів модернізації та переліку притаманних робіт у роботі [1], дають можливість припустити, що рекласифікація, дообладнання, реновація, практично не подовжують життєвий цикл судна, хоча перевагами цих напрямів будуть виступати термін виконання, номенклатура,незначна складність робіт та економічні затрати на виконання. В свою чергу реконструкція, переобладнання та конверсія вносять зміни безпосередньо в саму конструкцію судна і таким чином можуть подовжувати життєвий цикл (ЖЦ) судна. Відповідно терміни, витрати, складність робіт за цими напрямами будуть більшими. Існує доцільність проаналізувати напрями модернізації ПКС ВЗП відповідно до життєвого циклу судна, а саме - на якому етапі ЖЦ який 3 напрямів модернізації слід застосовувати, щоб оптимально подовжити строк ефективного використання судна за призначенням. 
Комерційним ризиком при проведенні модернізації судна буде отримання неоптимального судна після застосування обраного напряму модернізації. Щоб уникнути або максимально можливо зменшити ризик, в першу чергу необхідно проаналізувати небезпеки, що можуть привести до нього.

Мета статті. Визначити комплекс факторів, що призводять до модернізації ПКС ВЗП, ідентифікувати та проаналізувати небезпеки, частоту їх виникнення та виявити ризики, що можуть мати місце при проведенні напрямів модернізації.

Аналіз досліджень і публікацій. У 1997 році IMO розробила документ з метою оцінки безпеки судна «Guidelines for Formal Safety Assessment (FSA) for use in the IMO Rule-making process» [2]. За останні роки з`явилася значна кількість наукових досліджень та публікацій із застосуванням методики FSA, що свідчить про іiі універсальність та ефективність для оцінки ризиків і прийняття рішень у будь-якій галузі.

Єгоровим Г.В., Єгоровим А.Г. було досліджено надійність та ризики при експлуатації вітчизняного круїзного пасажирського флоту та проаналізовано випадки аварійних подій з 1983 по 2011 рік, пов 'язаних 3 корпусом, устаткуванням, пожежами, вибухами, механізмами РКПС $[3 ; 4]$.

Шахов А.В. у своїх працях пропонує застосовувати методику формалізованої оцінки безпеки при визначення номенклатури та обсягу ремонтних робіт в судноплавстві [5].

Олександровська Н.І. у дисертаційному дослідженні за допомогою FSA оцінює ризики при виборі стратегій технічного обслуговування та ремонту суден [6].

Сьомін О.А. в своєму дослідженні [8; 9] вперше використав методику FSA для оцінки комерційного ризику при проектуванні пасажир-ських суден, що дозволило скласти принципово новий підхід щодо визначення головних елементів ПСВЗП при проектуванні, враховуючи несприятливі техніко-експлуатаційні параметри.

Незважаючи на універсальність застосування методики FSA, на сьогодні не існує наукових праць щодо використання іiі для вивчення, аналізу та розробки проектів модернізації пасажирських суден ВЗП.

Таким чином, методичний апарат FSA може бути застосований при визначенні комерційних ризиків у результаті здійснення модернізаційних проектів ПКС ВЗП.

Викладення основного матеріалу. Важливим моментом при реалізації того чи іншого напряму модернізації ПКС ВЗП є визначення концепції модернізованого судна та засобів іiі технічної реалізації, оскільки некоректне визначення призведе до ризику отримання неконкурен-тоспроможного та збиткового судна. Насамперед, слід оцінити рівень комерційного ризику модернізації судна, тому що саме 
ВІСНИК

ОДЕСЬКОГО НАЦІОНАЛЬНОГО МОРСЬКОГО УНІВЕРСИТЕТУ
HERALD

OF THE ODESSA NATIONAL

MARITIME UNIVERSITY № 2 (59), 2019

комерційний

ризик вказує на ті фактори, що $є$ небезпеками для досягнення мети модернізації і отримання неефективного та неоптимального судна. 3 цією метою необхідно ідентифікувати та проаналізувати фактори (небезпеки), що призводять до модернізації ПКС ВЗП. На цьому етапі буде доцільним застосувати метод FSA.

Інформація для ідентифікації факторів, що призводять до модернізації судна протягом його життєвого циклу була отримана шляхом аналізу прикладів модернізації ПКС ВЗП України, Росії та Європи за останні 20 років. Зважаючи на це,можна виділити декілька причин (факторів), що призводять до модернізації пасажирських суден ВЗП (рис.1).

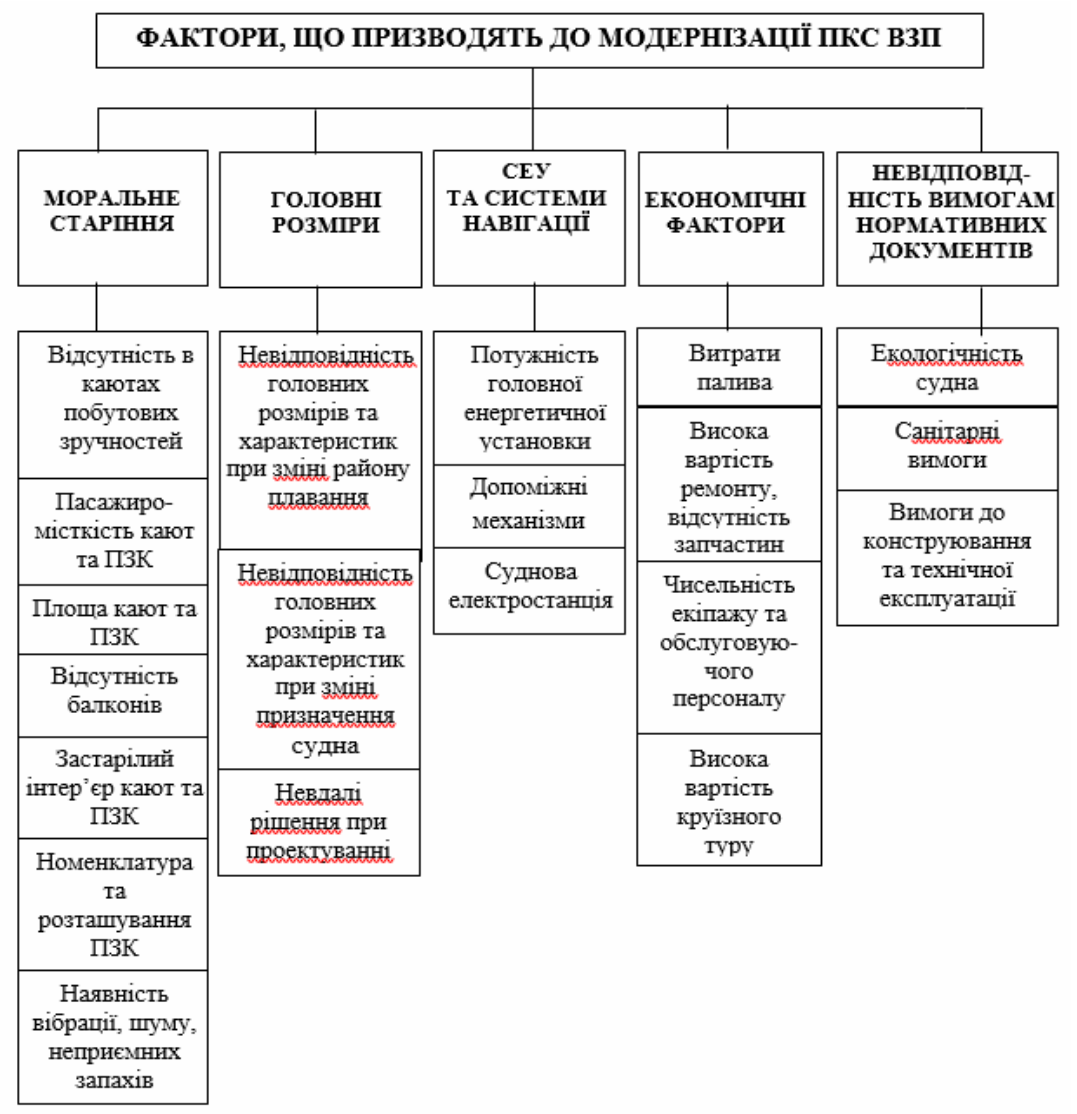

Рис.1. Дерево небезпек - факторів, щуо призводять до модернізації суден

1. Моральне старіння судна.

Будь-яка відмінність нових круїзних суден від існуючих призводить до зменшення привабливості останніх та морального старіння 
ПКС ВЗП. Низький рівень комфортабельності судна можна віднести до факторів морального старіння, ознаками якого є:

- відсутність в пасажирських каютах побутових зручностей, таких, як санвузол, душова кабіна або їх часткова наявність;

- завелика пасажиромісткість кают;

- замала пасажиромісткість приміщень загального користування (ПЗК);

- замала площа кают та ПЗК;

- відсутність балконів в каютах;

- застарілий (зношений) інтер'єр кают та ПЗК;

- номенклатура та розташування ПЗК;

- відсутність сучасних технічних систем оснащення кают та ПЗК (системи вентиляції, приготування питної води, інтернет-зв'язок, телебачення тощо);

- відсутність додаткового обладнання (ліфт, обладнання (пристрої) для людей з обмеженими можливостями тощо);

- наявність вібрації, шуму від суднових механізмів та систем, неприємні запахи.

У відповідності до вимог сучасного круїзного ринку судно повинно не лише мати комфортабельні каюти та приміщення загального користування, а бути комфортабельним в цілому.

2. Головні розміри та характеристики судна.

Аналіз проведених робіт з модернізації ПКС ВЗП свідчить про те, що головні розміри та характеристики, а саме висота, довжина, ширина, осадка судна, висота надводного борту є причинами для модернізації в наступних випадках:

- переведення судна з одного до іншого району плавання;

- зміна призначення виконуваних функцій судна;

- невірно визначена концепція судна на різних етапах проектування, невдалі технічні рішення при проектуванні.

3. Суднова енергетична установка, а саме: потужність головної енергетичної установки, допоміжних механізмів, суднової електростанції $\epsilon$ важливим фактором при модернізації суден. Внаслідок переобладнань на судні, розширення площі, номенклатури приміщень, встановлення сучасних систем, додаткового обладнання, що підвищують комфортабельність судна в цілому, збільшується енергоспоживання, що зумовлює необхідність модернізації суднової енергетичної установки, допоміжних механізмів, суднової електростанції.

4. Економічні фактори:

- високі витрати палива;

- висока вартість ремонту та нестача необхідних запчастин;

- зависока або недостатня чисельність екіпажу та обслуговуючого персоналу; 
- зависока ціна круїзного туру.

Значні витрати палива, висока вартість ремонту судна, велика чисельність обслуговуючого персоналу (витрати на заробітну плату) впливають на вартість круїзних путівок, як наслідок знижується попит на послуги круїзного ринку. В таких випадках судно економічно не вигідно використовувати за призначенням, що призводить до необхідності модернізації ПКС, в тому числі зі зміною призначення та окремих функцій судна.

5. Невідповідність судна міжнародним стандартам судноплавства та нормативам класифікаційних товариств. Модернізаційні роботи часто пов'язані з підвищенням стандартів безпеки судноплавства і виконанням вимог контролюючих організацій щодо конструювання та технічної експлуатації, екологічності суден, санітарних норм.

Для оцінки факторів (небезпек), що призводять до модернізації ПКС ВЗП були застосовані міжнародні нормативні документи 3 ймовірнісних методів оцінки ризиків[10; 11]. Застосування даних методів дозволило визначити фактори, що найчастіше призводять до модернізації ПКС ВЗП, і які можуть бути ризиками при проведенні напрямів модернізації. Процедура оцінки ризиків складається 3 декількох послідовних етапів: виявлення небезпек, оцінка ризику, визначення можливостей керування ризиком, розробка рекомендацій для кінцевого рішення. Детальний аналіз небезпек та ризиків здійснених проектів модернізації ПКС ВЗП є складовою частиною при створенні методики в галузі оновлення існуючих ПКС ВЗП, що надасть можливість обирати найбільш ефективний напрям модернізації відповідно до життєвого циклу судна.

Відносна частота виникнення небезпеки (фактору ризику, що зумовлює комерційну ефективність судна) визначається за формулою [12]

$$
W(A)=\frac{m}{n},
$$

де $m$ - число появи події, а $n$ - загальне число випробувань.

Стосовно тематики даної роботи формула (1) була перетворена в наступну залежність:

$$
W=\frac{S}{N_{S}}
$$

де $S$ - кількість суден, що впливають на підвищення визначеної небезпеки;

$N s$ - загальна кількість проаналізованих суден.

Результати визначення частоти виникнення $\mathrm{W}$ для кожного фактора ризику приведені в таблицях 1, 2 . 
Таблиия 1

Відносна частота появи небезпеки для суден України, Росії, Білорусі

\begin{tabular}{|l|c|c|c|}
\hline \multicolumn{1}{|c|}{ Фактор ризику } & $N S$ & $S$ & $W$ \\
\hline Моральне старіння & 128 & 119 & 0,93 \\
\hline Головні розміри та характеристики судна & 128 & 10 & 0,08 \\
\hline Суднова енергетична установка & 128 & 47 & 0,37 \\
\hline Економічні фактори & 128 & 10 & 0,08 \\
\hline $\begin{array}{l}\text { Невідповідність судна вимогам } \\
\text { нормативних документів }\end{array}$ & 128 & 20 & 0,16 \\
\hline
\end{tabular}

Таблиия 2

Відносна частота появи небезпеки для суден Західної Європи

\begin{tabular}{|l|c|c|c|}
\hline \multicolumn{1}{|c|}{ Фактор ризику } & $N S$ & $S$ & $W$ \\
\hline Моральне старіння & 39 & 34 & 0,87 \\
\hline $\begin{array}{l}\text { Головні розміри та характеристики } \\
\text { судна }\end{array}$ & 39 & 2 & 0,05 \\
\hline Суднова енергетична установка & 39 & 2 & 0,05 \\
\hline Економічні фактори & 39 & 3 & 0,08 \\
\hline $\begin{array}{l}\text { Невідповідність судна вимогам } \\
\text { нормативних документів }\end{array}$ & 39 & 3 & 0,08 \\
\hline
\end{tabular}

Проведені розрахунки свідчать, що головним фактором який зумовлює проведення модернізації як вітчизняних ПКС ВЗП, так і Західної Європиє моральне старіння. Отримані значення відносної частоти $W$ можна прийняти за наближене значення ймовірності появи небезпеки [12].

Для побудови матриць ризику для існуючих ПКС ВЗП України, Росії та Західної Європи, для кожної з небезпек в таблицях 1, 2 визначено рівень ризику $R$. Індекси імовірності $P$ присвоєні за п'ятибальною шкалою, виходячи 3 діапазону відносної частоти $W$ можливого негативного впливу на проект модернізації (табл. 3).

Таблиия 3

Індекси ймовірності впливу відносної частоти на проект модернізації

\begin{tabular}{|c|c|c|}
\hline Індекс $P$ & Діапазон відносної частоти $W$ & Імовірність впливу \\
\hline$\ll 1 »$ & $0-0,20$ & дуже незначна \\
\hline$\ll 2 »$ & $0,21-0,40$ & незначна \\
\hline$\ll 3 »$ & $0,41-0,60$ & значна \\
\hline$\ll 4 »$ & $0,61-0,80$ & суттєва \\
\hline
\end{tabular}


ВІСНИК

ОДЕСЬКОГО НАЦІОНАЛЬНОГО

МОРСЬКОГО УНІВЕРСИТЕТУ

№ 2 (59), 2019
HERALD

OF THE ODESSA NATIONAL

MARITIME UNIVERSITY

№ 2 (59), 2019

$\ll 5 »$

$0,81-1,00$

висока

Ймовірність впливу відносної частоти небезпеки (індекси Р) для проаналізованих суден розподілені наступним чином (табл.3).

Виходячи 3 аналізу наслідків впливу небезпек на існуючі ПКС ВЗП перерахованих вище небезпек, індекси були розподілені наступним чином:

- для суден України, Росії, Білорусі:

«5»- моральне старіння;

«2»- суднова енергетична установка;

«1» - невідповідність судна вимогам нормативних документів; головні розміри та характеристики судна; економічні фактори;

- для суден Західної Європи:

«5»- моральне старіння;

«1»- невідповідність судна вимогам нормативних документів; економічні фактори; головні розміри та характеристики судна; суднова енергетична установка.

При визначенні наслідків $C$ також використовувалась п'ятибальна шкала, відповідно до якої наслідкам небезпек були надані наступні індекси (табл.4):

Таблиия 4

Індекси небезпек відповідно наслідків впливу на проект модернізаиії

\begin{tabular}{|c|l|}
\hline Індекс $C$ & \multicolumn{1}{|c|}{ Наслідки впливу небезпек } \\
\hline «5» & $\begin{array}{l}\text { здатні катастрофічно вплинути на проект } \\
\text { модернізації, і не дозволять ефективно експлуатувати } \\
\text { судно після його проведення }\end{array}$ \\
\hline «4» & $\begin{array}{l}\text { критично впливають на проведення модернізації, } \\
\text { експлуатація судна буде неефективною }\end{array}$ \\
\hline «3» & $\begin{array}{l}\text { значні, але піддаються корегуванню з метою } \\
\text { підвищення ефективності судна }\end{array}$ \\
\hline «2» & $\begin{array}{l}\text { незначні і дозволяють експлуатувати судно без } \\
\text { значних перебудов та реконструкцій }\end{array}$ \\
\hline м1» & $\begin{array}{l}\text { мінімальні і не впливають істотно на експлуатацію та } \\
\text { утримання судна }\end{array}$ \\
\hline
\end{tabular}

«5»- моральне старіння;

«4» - суднова енергетична установка;

«3» - головні розміри та характеристики судна;

«2»- невідповідність судна вимогам нормативних документів;

«1»- економічні фактори. 
В якості оцінки рівня незначного ризику був обраний найнижчий рівень небезпеки 3 індексом «1», ймовірність впливу якого мінімальна $(W \leq 0,20)$ і не чинить значного впливу на ефективну експлуатацію судна після проведення модернізації. В якості рівня високого ризику обрано рівень небезпеки «5» $(W \geq 0,81)$.

Для оцінки рівня ризику було застосовано формулу [14]

$$
R=P x C .
$$

Дані розрахунків рівнів ризику приведені в таблицях 5, 6 .

Таблиия 5

Рівні ризику при модернізащії ПКС ВЗП України та Росії

\begin{tabular}{|l|c|c|c|}
\hline Небезпека & $P$ & $C$ & $R=P x C$ \\
\hline Моральне старіння & 5 & 5 & 25 \\
\hline Головні розміри та характеристики & 1 & 3 & 3 \\
\hline Суднова енергетична установка & 2 & 4 & 8 \\
\hline Економічні фактори & 1 & 1 & 1 \\
\hline $\begin{array}{l}\text { Невідповідність судна вимогам } \\
\text { нормативних документів }\end{array}$ & 1 & 2 & 2 \\
\hline
\end{tabular}

Таблиия 6

Рівні ризику при модернізачї ПКС ВЗП Західної Європи

\begin{tabular}{|l|c|c|c|}
\hline \multicolumn{1}{|c|}{ Небезпека } & $P$ & $C$ & $R=P x C$ \\
\hline Моральне старіння & 5 & 5 & 25 \\
\hline Головні розміри та характеристики & 1 & 3 & 3 \\
\hline Суднова енергетична установка & 1 & 4 & 4 \\
\hline Економічні фактори & 1 & 1 & 1 \\
\hline $\begin{array}{l}\text { Невідповідність судна вимогам } \\
\text { нормативних документів }\end{array}$ & 1 & 2 & 2 \\
\hline
\end{tabular}

Згідно $з$ даними таблиць 5, 6 побудовані матриці ризику ПКС ВЗП України, Росії, Білорусі, Західної Європи (рис. 2, 3). Цифри навпроти точок визначають наступні види небезпек: 1 - моральне старіння; 2 - головні розміри та характеристики судна; 3 - суднова енергетична установка; 4 - економічні фактори; 5 - невідповідність судна вимогам нормативних документів. 


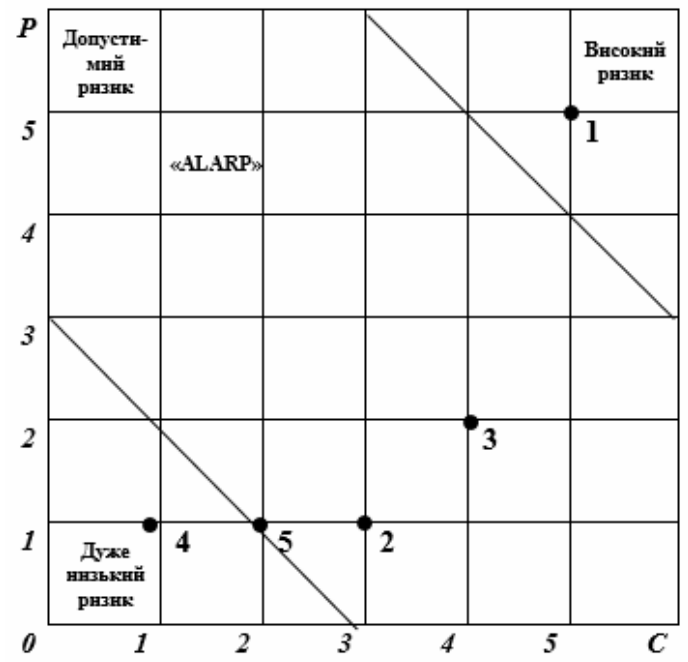

Рис. 2. Матриия ризику для ПКС ВЗП України, Росї, Білорусі

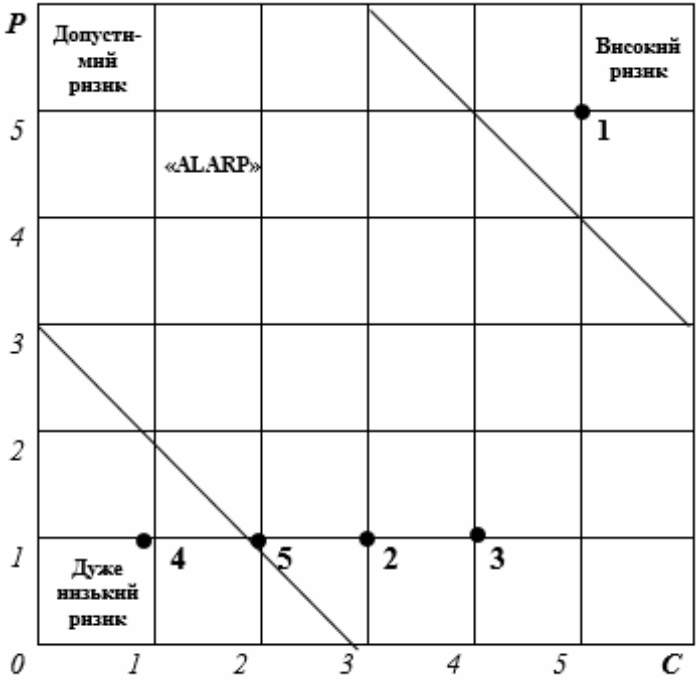

Рис. 3. Матриия ризику для ПКС ВЗП Західної Європи

Побудовані матриці наочно відображають, що при виконанні модернізації ПКС ВЗП такий вид небезпеки, як моральне старіння судна знаходиться в зоні «високого ризику», економічні фактори та невідповідність нормативним вимогам контролюючих організацій - в зоні «низького ризику», а суднова енергетична установка та головні розміри $\mathrm{i}$ характеристики судна посідають місце в зоні «допустимого ризику», причому як вітчизняних, так і суден Західної Європи. 
Таким чином, матриці дають чітке уявлення про те, що найбільшим ризиком при виконанні проектів модернізації ПКС ВЗП є моральне старіння суден. Зважаючи на значимість саме цього фактору, буде доцільним окремо проаналізувати небезпеки всередині фактору «моральне старіння», застосовуючи методику FSA, а також визначити методи усунення наведених ризиків.

Висновки. На сьогодні не існує наукових праць щодо використання методики FSAдля вивчення, аналізу та розробки проектів модернізації ПКС ВЗП.

Проведені розрахунки та матриці ризику дають уявлення про те, що максимальним фактором ризику при виконанні модернізації ПКС ВЗП України, Росії та Західної Свропи буде моральне старіння суден, в зоні низького ризику - економічні фактори та невідповідність нормативним вимогам контролюючих організацій, допустимий ризик мають суднова енергетична установка та головні розміри і характеристики судна.

Зважаючи на значимість саме цього фактору, буде доцільним окремо проаналізувати небезпеки всередині фактору «моральне старіння», застосовуючи метод FSA.

Засобами для усунення морального старіння судна 3 метою подовження життєвого циклу судна та ефективної експлуатації будуть напрями модернізації судна, визначені у [1].

\section{СПИСОК ЛІТЕРАТУРИ}

1. Кукалеи Л.Н. Идентификаиия и классификаџия направлений обновления круизного пассажирского флота смешанного и внутреннего плавания / Л.Н.Кукалеи // Вестник ОНМУ. Odecca: OHMУ, 2018. Buin. 54. C.61-72.

2. Consolidated text of the Guidelines for Formal Safety Assessment (FSA) for use in the IMO Rule-making process. (MSC/Circ. $1023-$ MERC/Circ. 392). 14.05.2007

3. Егоров Г.В. Исследование риска аварий корпусов транспортних судов ограниченных районов плавания за 1991-2010 годы / Г.В.Егоров // Вестник ОНМУ. Одесса: ОНМУ, 2010. Bыn. 30. C. 53-76.

4. Егоров Г.В. Исследование надежности и риска эксплуатащии отечественных речных круизных пассажсирских судов / Г.В. Егоров, А.Г. Егоров // Вестник ОНМУ. Одесса: ОНМУ, 2015. Buln. 1(43). C. 5-32. 
ВІСНИК

ОДЕСЬКОГО НАЦІОНАЛЬНОГО

МОРСЬКОГО УНІВЕРСИТЕТУ № 2 (59), 2019
HERALD

OF THE ODESSA NATIONAL

MARITIME UNIVERSITY

5. Шахов А.В. Управление рисками в судоремонтных проектах / А.В. Шахов, М.О. Бокарева // Вісник НТУ «ХПІ». Серія: Стратегічне управління, управління портфелями, програмами та проектами. Х.: НТУ «ХПI», 2014. № 2 (1045). С. 81-86.

6. Александровская Н.И. Управление жизненным ичиком судна путем усовершенствования стратеги технического обслуживания и ремонта: Дис. ... канд. техн. наук: 05.22.20 / Н.И. Александровская. Одесса: ОНМУ, 2003.

7. Александровская Н.И. Рискоориентированная стратегия технического обслуживания и ремонта судов / Н.И. Александровская, В.И. Шахов, А.В. Шахов // Зб. наук. прачь «Методи та засоби управління розвитком транспортних систем». Одесса, 2011. № 17. C. 7-17.

8. Сёмин А.А. Идентификация и оценка рисков при проектировании пассажсирских судов внутреннего и смешанного плавання / А.А. Сёмин // Вісник Одеського національного морського університету: 3б. наук. праџь. Одеса: ОНМУ, 2011. Bыn. 33. C.69-77.

9. Сёмин А.А. Учёт критерия комфортабельности при проектировании пассажирских судов внутреннего и смешанного плавания [Текст]: Дис. ... канд. техн. наук: 05.08.03 / Сёмин Алексей Анатольевич. Одесса, 2013. 139 с. C 4-119.

10. Revised guidelines for formal safety assessment (FSA) foruseintheimorule-makingprocess/MSC-MEPC.2/Circ.12/Rev.2 9 April 2018.[Електронний ресурс]. Режим доступу: https://www.transportstyrelsen.se/contentassets/49eae9a745 de401 bafe249d5ed95b75c/12-rev2.pdf. Дата звернення: 17.01.2019 p.

11. Руководство по управлению рисками (Risk Management Guide). Российский морской регістр судоходства, 2010. [Електронний pecypc]. Режим достуny: https://navlib.net/wp-content/ uploads/ 2017/01/Руководство по определению риска. Дата звернення: $22.08 .2018 p$.

12. Гмурман В.Е. Теория вероятностей и математическая статистика: Учебн. пособие для вузов / В.Е. Гмурман. 9-е изд. М.: Высшая школа, 2003. 479 c.

13. Топалов В.П. Формализованная оченка безопасности (FSA) сущность и применение в судоходстве: Учебн. пособие / В.П. Топалов, В.Г. Торский, В.В. Торский; ИКЦ Одес. наи. мор. акад., Отд-ние Мор. ин-та Великобритании в Украине (Мор. ин-т Украины), Укр. асои. по защите моря от загрязнений (УКРМЕПА). Одесса: Астропринт, 2013. 94 c. 
14. Емельянов М.Д. Оиенка риска и критичне элементы морских судов / М.Д. Емельянов // Проблемь развития морского флота: Сб. научн. трудов ЗАО «ЦНИИМФ». СПб, 2009. C. 20-41.

\section{REFERENCES}

1. Kukalec L.N. (2018) Identifikaciya i klassifikaciya napravlenij obnovleniya kruiznogo passazhirskogo flota smeshannogo $i$ vnutrennego plavaniya [Identification and classification of renewal ways of cruise passenger fleet of coastal and inland navigation] Vestnik ONMU, no. 54. pp.61-72.

2. Revised guidelines for formal safety assessment (FSA) for use in the imo rule-making process (MSC-MEPC.2/Circ.12/Rev.2/ 9 April 2018) Available at: http://www.imo.org/en/OurWork/ Safety/ SafetyTopics/ Documents/MSC-MEPC\%202-Circ\%2012Rev\% 202. pdf accessed 17/12/2019)

3. Egorov G.V. (2010) Issledovanie riska avarij korpusov transportnyh sudov ogranichennyh rajonov plavaniya za 19912010 gody [Study of the risk of accidents of transport vessels of limited navigation areas for 1991-2010] Vestnik ONMU, no. 30. pp. 53-76.

4. Egorov G.V., Egorov A.G. (2015) Issledovanie nadezhnosti i riska ekspluatacii otechestvennyh rechnyh kruiznyh passazhirskih sudov [The study of the reliability and risk of operation of domestic river cruise passenger ships] Vestnik ONMU, no. 1(43). pp. 5-32.

5. Shahov A.V., Bokareva M.O. (2014) Upravlenie riskami v sudoremontnyh proektah [Risk Management in ship-repairprojects] NTU «HPI». Seriya : Strategichne upravlinnya, upravlinnya portfelyami, programami ta proektami. No. 2 (1045). pp. 81-86

6. Aleksandrovskaya N.I. (2003) Upravlenie zhiznennym ciklom sudna putem usovershenstvovaniya strategii tehnicheskogo obsluzhivaniya i remonta [Management by the life cycle of ship by the improvement of strategy of technical service and repair] Dis. ... kand. tehn. nauk: 05.22.20. Odessa: ONMU.

7. Aleksandrovskaya N. I., Shahov V.I., Shahov A.V. (2011) Riskoorientirovannaya strategiya tehnicheskogo obsluzhivaniya $i$ remonta sudov [Project-oriented strategy of technical service andrepair of courts]. Odessa: Metodi ta zasobi upravlinnya rozvitkom transportnih sistem. No. 17. pp. 7-17. 
ВІСНИК

ОДЕСЬКОГО НАЦІОНАЛЬНОГО

МОРСЬКОГО УНІВЕРСИТЕТУ

№ 2 (59), 2019
HERALD

OF THE ODESSA NATIONAL

MARITIME UNIVERSITY

8. Syomin A.A. (2011) Identifikaciya i ocenka riskov pri proektirovanii passazhirskih sudov vnutrennego $i$ smeshannogo plavannya [Authentication and estimation of risks at planning of passengercourts of the internal and mixed swimming] Odessa: Vestnik ONMU. No. 33. pp. 69-77.

9. Syomin A.A. (2013) Uchyot kriteriya komfortabelnosti pri proektirovanii passazhirskih sudov vnutrennego i smeshannogo plavaniya [Account of criterion of comfort at planning of passenger courtsof the internal and mixed swimming]: Dis. ... kand. tehn. nauk: 05.08.03. Odessa: ONMU, $139 \mathrm{pp}$.

10. Gmurman, V.E. (2003) Teoriya veroyatnostej $i$ matematicheskaya statistika [Theory of chances and mathematicalstatistics] Moscow: Vysshaya shkola.

11. Topalov V.P. Torskij V.G., Torskij V.V. (2013) Formalizovannaya ocenka bezopasnosti (FSA) - sushnost i primenenie v sudohodstve [formal safety assessment (FSA) is essenceand application in a navigation]. Odessa: Astroprint.

12. Emelyanov M.D. (2009) Ocenka riska i kritichnye elementy morskih sudov [Risk estimation and critical elements of marine ships] SPb. Problemy razvitiya morskogo flota: Sb. nauchnyh trudov $Z A O « C N I I M F »$. pp. 20-41.

Стаття надійшла до редакиії 30.10.2019

\section{Рещензенти:}

доктор технічних наук, доцент, директор Київського інституту водного транспорту Державного університету інфраструктури та технологій (КІВТ ДУІТ) О.М. Тимощук

кандидат технічних наук, доцент, декан факультету експлуатації технічних систем на водному транспорті Київського інституту водного транспорту Державного університету інфраструктури та технологій (КІВТ ДУІТ) О.А. Сьомін 